\title{
PENGETAHUAN, SIKAP, DAN PERILAKU PENJUAL TERHADAP PELARANGAN PENGGUNAAN KANTONG BELANJA PLASTIK SEKALI PAKAI DI PASAR TRADISIONAL BADUNG KOTA DENPASAR
}

\author{
Elbena Bani Nathania*, I Gede Herry Purnama \\ Program Studi Kesehatan Masyarakat Fakultas Kedokteran Universitas Udayana \\ *email: siregarelbena@yahoo.com
}

\begin{abstract}
ABSTRAK
Indonesia merupakan Negara kedua penyumbang sampah plastik yang dibuang ke laut pada tahun 2015 mencapai 187,2 juta ton. Beberapa kota di Indonesia akhirnya melakukan diet plastik, sebagai upaya untuk mengurangi penggunaan kantong plastik termasuk Denpasar. Pemerintah kota Denpasar mengeluarkan Peraturan Wali Kota (Perwali) Nomor 36 Tahun 2018 mengenai pelarangan penggunaan kantong plastik di Denpasar pada pusat perbelanjaan dan pasar modern pada tanggal 1 Januari 2019. Penelitian ini bertujuan untuk mengetahui pengetahuan, sikap, dan perilaku penjual terhadap pelarangan penggunaan kantong belanja plastik sekali pakai di pasar Badung kota Denpasar. Penelitian ini menggunakan metode cross-sectional dengan total sampel penjual di Pasar Badung sebanyak 86 orang. Pengambilan data dilakukan secara langsung kepada penjual dengan wawancara menggunakan kuesioner pengetahuan, sikap, dan perilaku. Teknik pengambilan sampel menggunakan convenience sampling pada penjual di Pasar Badung. Analisis data menggunakan analisis univariat secara deskriptif. Hasil penelitian menunjukan bahwa penjual yang berpengetahuan baik (53,49\%), sikap baik $(55,81 \%)$ dan perilaku kurang baik (50\%). Hasil penelitian ini menunjukkan bahwa responden memiliki pengetahuan dan sikap baik namun masih banyak responden yang berperilaku kurang baik.
\end{abstract}

Kata kunci: Pengetahuan, Sikap, Perilaku, Plastik

\section{ABSTRACT}

Indonesia is the second-largest contributor of plastic waste thrown into the sea in 2015 which reached 187.2 million tons. Some cities in Indonesia finally went on a plastic diet, as an effort to reduce the use of plastic bags, including Denpasar. Denpasar city government issued Major Regulation (Perwali) No. 36 of 2018 concerning a ban on the use of plastic bags in Denpasar in shopping centers and modern markets on January 1, 2019. This study aims to determine the knowledge, attitudes, and behavior of sellers against the ban on the use of disposable plastic shopping bags in Badung traditional market in the city of Denpasar. This study used a cross-sectional method with a total sample of 86 sellers in Badung Market. Data was collected directly to the seller by interview using a knowledge, attitude and behavior questionnaire. The sampling technique used is convenience sampling to the sellers in Badung Market. Data analysis was performed with univariat analysis descriptively. The results of the study indicate that the seller was knowledgeable (73.26\%), good attitude (79.07\%) and bad behavior (73.26\%). The results of this study also indicate that respondents have good knowledge and attitude but there are still many respondents who behave badly.

Keywords: Knowledge, Attitude, Behavior, Plasti

\section{PENDAHULUAN}

Sampah merupakan salah satu dari sekian banyaknya permasalahan di dunia, termasuk Indonesia. Persoalan ini belum sepenuhnya dituntaskan. Alasan yang membuat volume sampah terus meningkat disebabkan oleh banyak faktor seperti pola hidup masyarakat, kepadatan penduduk, dan budaya konsumtif yang kian hari makin meningkat. Sampah menurut World Health Organization (WHO) merupakan sesuatu yang tidak digunakan, tidak dipakai, tidak disenangi atau sesuatu yang dibuang yang berasal dari kegiatan manusia dan tidak terjadi dengan sendirinya (Chandra, 2006). Sampah sendiri terbagi atas dua yaitu sampah 
organik dan anorganik. Sampah anorganik merupakan sampah yang sulit terurai oleh bakteri dan tidak mudah busuk seperti kain, plastik, kertas, kaleng, sterofoam, dan lain sebagainya. Plastik merupakan salah satu bahan yang sering digunakan oleh manusia untuk berbagai hal, salah satunya untuk membawa barang belanjaan. Karakteristik plastik yang susah diurai oleh tanah dan sulit hancur meskipun sudah terkubur di dalam tanah selama puluhan tahun menjadi alasan besar plastik memiliki dampak buruk bagi lingkungan.

Indonesia merupakan negara kedua penyumbang sampah plastik yang dibuang ke laut pada tahun 2015 diprakirakan mencapai 187,2 juta ton (sedangkan Tiongkok diprakirakan mencapai 262,9 juta ton) (CNN, 2016). Berdasarkan perhitungan tersebut, setiap orang yang berada di Indonesia menggunakan 700 tas plastik per tahun atau kira-kira dua kantong plastik dalam satu hari, kebiasaan masyarakat Indonesia memakai kantong plastik sekali pakai ini pun didukung dengan kantong plastik yang tidak berbayar atau gratis.

Untuk itu, pemerintah mengeluarkan surat edaran tas plastik berbayar pada tahun 2016. Kebijakan itu dilaksanakan berdasarkan Surat Edaran Kementerian Lingkungan Hidup dan Kehutanan Nomor S.1230/PSLB3-PS /2016 tentang Harga dan Mekanisme Penerapan Kantong Plastik Berbayar (Ekawati, 2016). Di dalam aturan itu, disepakati kantong plastik berbayar Rp 200 sudah termasuk Pajak Pertambahan Nilai (PPN) (Mintarsih, 2019). Di sejumlah kota yang diamati, masyarakat cenderung untuk membeli kantong plastik yang disediakan toko dibandingkan membawa kantong belanja sendiri. Padahal, surat edaran Kementrian Lingkungan Hidup dan Kehutanan itu dimaksudkan untuk membatasi penggunaan plastik yang dianggap merusak lingkungan (Ismail, 2016).

Beberapa kota di Indonesia akhirnya melakukan diet plastik, sebagai upaya untuk mengurangi penggunaan kantong plastik. Pada tanggal 1 Januari 2019 Pemerintah kota Denpasar mengeluarkan Peraturan Wali Kota (Perwali) Nomor 36 Tahun 2018 telah diberlakukan pelarangan penggunaan kantong plastik di Denpasar pada pusat perbelanjaan dan pasar modern (Denpasar, 2018). Pelarangan penggunaan kantong plastik sebagai tas belanja ini diharapkan dapat menurunkan timbulan sampah plastik sampai 50 persen di akhir tahun. Kebijakan terkait dalam pengurangan penggunaan kantong plastik yang mengikat ini menjadikan masyarakat terutama pelaku usaha atau pedagang di pasar mengubah perilaku mereka terkait konsumsi kantong plastik yang berlebihan. Perilaku penjual atau pedagang dengan adanya kebijakan terkait dalam pengurangan penggunaan kantong plastik juga dapat mempengaruhi sejauh mana keberhasilan peraturan tersebut dicapai.

Notoatmodjo (2014) menjelaskan bahwa secara biologis perilaku adalah suatu kegiatan atau aktivitas makhluk hidup, sehingga yang dimaksud dengan perilaku manusia adalah tindakan atau aktivitas dari manusia yang mempunyai artian sangat luas antara lain : berjalan, berbicara, menangis, tertawa, bekerja, kuliah, menulis, membaca, dan sebagainya. 
Untuk mengukur perilaku seseorang menurut teori Lawrence Green (1991 dalam Siswantoro, 2012:153) yaitu predisposing factors (faktor pemudah), enabling factors (faktor pemungkin), dan reinforcing factors (faktor penguat).

Menurut survey yang dilakukan tahun 2008 oleh mahasiswa Kesehatan Masyarakat Universitas Sumatera Utara ditemukan komposisi sampah non organik termasuk sampah plastik sudah meningkat $35 \%$, dan pasar tradisional menyumbang $70 \%$ sampah plastik yang tersebar di seluruh Indonesia artinya, sebagian besar sampah plastik yang sudah jelas berbahaya terhadap lingkungan itu berasal dari pasar tradisional. Walaupun demikian, dari data survey yang dilakukan oleh Kepala Dinas Lingkungan Hidup dan Kebersihan (DLHK) Kota Denpasar I Ketut Wisada, sejak Perwali Nomor 36 tahun 2018 diterapkan terdapat penurunan persentase penggunaan kantong plastik. Pada periode bulan Februari hingga April 2019, persentase penurunan penggunaan kantong belanja plastic bertambah mencapai 99,60\% atau sekitar 12.981.234 lembar jika dibandingkan dengan data pemakaian kantong plastik pada tahun 2018 atau sebelum Perwali Nomor 36 Tahun 2018 diberlakukan. Melalui penerapan Peraturan Walikota Denpasar No. 36 Tahun 2018 dan Instruksi Walikota Denpasar No. 1 Tahun 2018 ini, volume penggunaan kantong plastik pada pasar tradisional dan kegiatan usaha lainnya di Kota Denpasar telah mengalami penurunan dengan persentase penurunan masing- masing sebesar 54,26\% untuk pasar tradisional dan $86,27 \%$ untuk usaha lainnya yang berada di ruas-ruas jalan di Kota Denpasar (Kominfo, 2019).

Penelitian ini akan dilakukan pada penjual pada Pasar Badung. Kuesioner diberikan untuk mengetahui pengetahuan, sikap, serta perilaku penjual terhadap Peraturan Wali Kota Denpasar Nomor 36 Tahun 2018.

\section{METODE PENELITIAN}

Penelitian ini merupakan penelitian kuantitatif deskriptif dengan menggunakan pendekatan cross-sectional. Penelitian ini dilaksanakan di Pasar Badung di Denpasar pada bulan Agustus-Oktober 2019. Teknik sampling yang digunakan adalah convenience sampling sebanyak 86 penjual di Pasar Badung. Sumber data yang dikumpulkan merupakan data primer kepada penjual menggunakan instrumen penelitian seperti kuesioner. Metode analisis data penelitian ini dilakukan dengan analisis univariat dengan menggunakan aplikasi software statistika yaitu STATA 12 dan SPSS. Analisis univariat dilakukan terhadap setiap variabel penelitian untuk mendistribusikan secara umum data hasil penelitian. Gambaran umum dilakukan dengan menggunakan distribusi frekuensi masingmasing variabel.

\section{HASIL DAN PEMBAHASAN Karakteristik Responden}

Karakteristik responden terdiri dari variabel jenis kelamin, umur, pendidikan terakhir, dan lama bekerja pada Tabel 1 . 
Tabel 1. Distribusi Karakteristik Responden

\begin{tabular}{|c|c|c|}
\hline Karakteristik & Frekuensi (n) & Proporsi (\%) \\
\hline \multicolumn{3}{|l|}{ Jenis Kelamin } \\
\hline Laki-laki & 17 & 19,80 \\
\hline Perempuan & 69 & 80,20 \\
\hline \multicolumn{3}{|l|}{ Umur } \\
\hline Remaja (17-25 Tahun) & 8 & 9,30 \\
\hline Dewasa (26-45 Tahun) & 33 & 38,37 \\
\hline Lansia ( $>45$ tahun) & 45 & 52,33 \\
\hline \multicolumn{3}{|l|}{ Pendidikan Terakhir } \\
\hline Dasar & 19 & 22,10 \\
\hline Menengah & 50 & 58,10 \\
\hline Tinggi & 17 & 19,80 \\
\hline \multicolumn{3}{|l|}{ Lama Bekerja (tahun) } \\
\hline$\leq 10$ tahun & 47 & 54,70 \\
\hline$>10$ tahun & 39 & 45,30 \\
\hline
\end{tabular}

Tabel 1 menunjukan bahwa responden paling banyak berada pada kelompok jenis kelamin perempuan 69 $(80,2 \%)$ dengan umur responden paling banyak pada kategori lansia $>45$ tahun sebanyak 52,33\%. Pendidikan terakhir paling banyak pada kategori menengah (SMP, SMA) sebanyak 58,10\%, dan lama bekerja sebanyak $54,70 \%$ pada lama bekerja $\leq 10$ tahun.

\section{Pengetahuan Penjual}

Pengetahuan penjual didapatkan dari hasil kuesioner terhadap para penjual di Pasar Badung di Denpasar dan dianalisis secara deskriptif pada tabel berikut.

Tabel 2a. Pengetahuan Penjual Terhadap Pelarangan Penggunaan Kantong Belanja Plastik

\begin{tabular}{lcc}
\hline \multicolumn{1}{c}{ Pengetahuan } & Frekuensi & Presentase (\%) \\
\hline Baik & 46 & $53,49 \%$ \\
Kurang & 40 & $46,51 \%$ \\
\hline
\end{tabular}

Diketahui bahwa secara umum tingkat pengetahuan penjual terhadap pelarangan penggunaan kantong belanja plastik di Pasar Badung termasuk dalam kategori baik dengan presentase 53,49\%. Dimana dari 86 responden yang diwawancarai sebanyak 46 responden memiliki pengetahuan yang baik (53,49\%), dan 40 responden memiliki pengetahuan yang kurang baik $(46,51 \%)$.

Hasil penelitian ini sejalan dengan penelitian yang dilakukan oleh Mira Guslaida (2014) menunjukkan bahwa pengetahuan pada pedagang tentang penggunaan kantong plastik di Pasar Tradisional Firdaus Kecamatan Medan Tembung Tahun 2014 umumnya berada pada kategori pengetahuan baik $(56,7 \%)$ sebanyak 34 responden dan kategori buruk (43,3\%) sebanyak 26 responden (Guslaida, 2014). Dilihat dari perolehan median sebesar 12 maka dapat dikatakan bahwa lebih dari setengah penjual mempunyai tingkat pengetahuan yang baik, hal tersebut ditunjukkan dengan lebih dari setengah penjual bisa menjawab sebanyak 6 dari 10 pertanyaan dengan benar. Jadi dapat 
Arc. Com. Health • Desember 2020

p-ISSN 2302-139X e-ISSN 2527-3620

Vol. 7 No. $2: 13$ - 20

dikatakan bahwa sebagian besar responden mempunyai pengetahuan yang baik dalam

pelarangan penggunaan kantong belanja plastik.

Tabel 2b. Pengetahuan Penjual Terhadap Pelarangan Penggunaan Kantong Belanja Plastik dengan Variabel

\begin{tabular}{lcc}
\hline \multicolumn{1}{c}{ Variabel } & Buruk & Baik \\
\hline Umur & & \\
Remaja (17-25 Tahun) & $2(25,00 \%)$ & $6(75,00 \%)$ \\
$\quad$ Dewasa (26-45 Tahun) & $16(48,48 \%)$ & $17(51,52 \%)$ \\
Lansia ( $>45$ tahun) & $22(48,89 \%)$ & $23(51,11 \%)$ \\
Jenis Kelamin & & \\
Laki-laki & $10(58,82 \%)$ & $7(41,18 \%)$ \\
Perempuan & $30(43,48 \%)$ & $39(56,52 \%)$ \\
Pendidikan Terakhir & & \\
Rendah & $11(57,89 \%)$ & $8(42,11 \%)$ \\
Menengah & $25(49,02 \%)$ & $26(50,98 \%)$ \\
Tinggi & $4(25,00 \%)$ & $12(75,00 \%)$ \\
Lama Bekerja (tahun) & & \\
$\leq 10$ tahun & $18(34,62 \%)$ & $34(65,38 \%)$ \\
$>10$ tahun & $22(64,71 \%)$ & $12(35,29 \%)$ \\
\hline
\end{tabular}

Selanjutnya pada tabel pengetahuan dengan variabel umur, jenis kelamin, pendidikan terakhir dan lama bekerja, pengetahuan baik responden terhadap pelarangan penggunaan kantong belanja plastik pada umur 17-25 tahun sebanyak 6 $(75,00 \%)$. Penjual dengan jenis kelamin perempuan sebanyak 39 (56,52\%) memiliki pengetahuan baik selain itu sebanyak 12 $(75,00 \%)$ penjual dengan pendidikan tinggi juga. Lama bekerja penjual dengan pengetahuan baik adalah $\leq 10$ tahun sebanyak 34 (65,38Sikap Penjual

Tabel 3a. Sikap Penjual Terhadap Pelarangan Penggunaan Kantong Belanja Plastik

\begin{tabular}{|c|c|c|}
\hline Sikap & Frekuensi & Presentase (\%) \\
\hline Baik & 48 & $55,81 \%$ \\
\hline Kurang & 38 & $44,19 \%$ \\
\hline
\end{tabular}

Secara umum diketahui bahwa dari 86 responden yang diwawancarai sebanyak 48 responden memiliki sikap yang baik (55,81\%), dan 38 responden memiliki sikap kurang baik $(44,19 \%)$.

Hasil penelitian ini sejalan dengan penelitian yang dilakukan oleh Heryanto Sumbung (2012) menunjukkan bahwa sikap responden dalam mengurangi penggunaan kantong plastik, sebesar $87,1 \%$ atau 61 orang responden memiliki sikap baik, sebesar $10 \%$ atau 7 orang responden memiliki sikap sedang dan sebesar 2,9\% atau 2 orang responden memiliki sikap tidak baik (Sumbung, 2012). 
Tabel 3b. Sikap Penjual Terhadap Pelarangan Penggunaan Kantong Belanja Plastik dengan Kara

\begin{tabular}{lrr}
\hline \multicolumn{1}{c}{ Variabel } & \multicolumn{1}{c}{ Buruk } & \multicolumn{1}{c}{ Baik } \\
\hline Umur & & \\
Remaja (17-25 Tahun) & $3(37,50 \%)$ & $5(62,50 \%)$ \\
$\quad$ Dewasa (26-45 Tahun) & $17(51,52 \%)$ & $16(48,48 \%)$ \\
Lansia ( $>45$ tahun) & $18(40,00 \%)$ & $27(60,00 \%)$ \\
Jenis Kelamin & & \\
Laki-laki & $11(64,71 \%)$ & $6(35,29 \%)$ \\
Perempuan & $27(39,13 \%)$ & $42(60,87 \%)$ \\
$\begin{array}{l}\text { Pendidikan Terakhir } \\
\text { Rendah }\end{array}$ & $6(31,58 \%)$ & $13(68,42 \%)$ \\
Menengah & $22(43,14 \%)$ & $29(56,86 \%)$ \\
Tinggi & $10(62,50 \%)$ & $6(37,50 \%)$ \\
Lama Bekerja (tahun) & & $30(57,69 \%)$ \\
$\leq 10$ tahun & $22(42,31 \%)$ & $18(52,94 \%)$ \\
$>10$ tahun & $16(47,06 \%)$ & \\
\hline
\end{tabular}

Selanjutnya pada tabel pada tabel sikap dengan variabel umur, jenis kelamin, pendidikan terakhir dan lama bekerja, sikap baik penjual terhadap pelarangan penggunaan kantong belanja plastik didominasi oleh umur remaja (17-25 tahun) sebanyak 5 (62,50\%). Penjual dengan jenis kelamin perempuan sebanyak $42(60,87 \%)$ memiliki sikap baik. Sikap baik penjual dengan pendidikan terakhir rendah sebanyak $13(68,42 \%)$ dan dengan lama bekerja $\leq 10$ tahun sebanyak 30 (57,69\%).

Perilaku Penjual

Tabel 4a. Perilaku Penjual Terhadap Pelarangan Penggunaan Kantong Belanja Plastik

\begin{tabular}{|c|c|c|}
\hline Perilaku & Frekuensi & Presentase (\%) \\
\hline Baik & 43 & $50,00 \%$ \\
\hline Kurang & 43 & $50,00 \%$ \\
\hline
\end{tabular}

Secara umum, dapat diketahui bahwa dari 43 responden memiliki perilaku yang baik $(50 \%)$, dan 43 responden memiliki perilaku kurang baik (50\%).

Hasil penelitian ini sejalan dengan penelitian yang dilakukan oleh Guslaida (2014) menunjukkan bahwa perilaku pada pedagang tentang penggunaan kantong plastik di Pasar Tradisional Firdaus Kecamatan Medan Tembung Tahun 2014 umumnya berada pada kategori buruk berjumlah 31 atau $(51,7 \%)$ sedangkan jumlah penggunan kantong plastik pada kategori baik berjumlah 29 atau (48,3\%).

Tabel 4b. Perilaku Penjual Terhadap Pelarangan Penggunaan Kantong Belanja Plastik dengan Variabel

$\begin{array}{lll}\text { Variabel } & \text { Buruk } & \text { Baik }\end{array}$




\begin{tabular}{lrr}
\hline Umur & & \\
Remaja (17-25 Tahun) & $4(50,00 \%)$ & $4(50,00 \%)$ \\
$\quad$ Dewasa (26-45 Tahun) & $14(42,42 \%)$ & $19(57,58 \%)$ \\
Lansia ( $>45$ tahun) & $25(55,56 \%)$ & $20(44,44 \%)$ \\
Jenis Kelamin & & \\
Laki-laki & $6(35,29 \%)$ & $11(64,71 \%)$ \\
$\begin{array}{l}\text { Perempuan } \\
\text { Pendidikan Terakhir }\end{array}$ & $37(53,62 \%)$ & $32(46,38 \%)$ \\
Rendah & & \\
Menengah & $13(68,42 \%)$ & $6(31,58 \%)$ \\
Tinggi & $26(50,98 \%)$ & $25(49,02 \%)$ \\
Lama Bekerja (tahun) & $4(25,00 \%)$ & $12(75,00 \%)$ \\
$\leq 10$ tahun & & \\
$>10$ tahun & $23(44,23 \%)$ & $29(55,77 \%)$ \\
\hline
\end{tabular}

Berdasarkan tabel $4 \mathrm{~b}$ di atas, perilaku baik didapatkan pada kategori umur dewasa (26-45 tahun) sebanyak 19 (57,58\%). Pada penjual dengan jenis kelamin laki-laki didapati perilaku baik yaitu 11 (64,71\%). Pendidikan terakhir dengan perilaku baik adalah pendidikan tinggi sebanyak 12 (75,00\%). Penjual dengan lama bekerja $\leq 10$ tahun memiliki perilaku baik sebanyak 29 (55,77\%). Sedangkan dari perilaku kurang baik terdapat pada kategori umur lansia ( $>45$ tahun) sebanyak $25(55,56 \%)$, jenis kelamin perempuan sebanyak 37 (53,62\%), pendidikan rendah $13(68,42 \%)$, dan lama bekerja $>10$ tahun sebanyak 20 (58,82\%).

\section{SIMPULAN}

Penelitian yang dilakukan terhadap 86 penjual di Pasar Badung Denpasar menunjukkan bahwa tingkat pengetahuan penjual yang diwawancarai sebanyak 46 responden memiliki pengetahuan yang baik (53,49\%), serta 40 responden memiliki pengetahuan kurang baik (46,51\%). Sikap penjual terhadap Peraturan Wali Kota Denpasar Nomor 36 Tahun 2018 terkait pengurangan penggunaan kantong plastik sekali pakai memiliki sikap yang baik sebanyak 48 responden $(55,81 \%)$, dan 38 responden memiliki sikap kurang baik
(44,19\%). Perilaku penjual terhadap Peraturan Wali Kota Denpasar Nomor 36 Tahun 2018 terkait pengurangan penggunaan kantong plastik sekali pakai memilki 43 responden (50,00\%), dan 43 responden memiliki perilaku yang baik $(50,00 \%)$.

\section{SARAN}

Pada penelitian ini perilaku penjual terhadap Peraturan Wali Kota Denpasar Nomor 36 Tahun 2018 terkait pengurangan penggunaan kantong plastik sekali sebagian besar kurang baik. Diharapkan perilaku penjual kedepannya dapat dioptimalkan guna terbentuknya perilaku yang baik terhadap penggunaan kantong plastik sekali pakai. Saran kepada pihak terkait atau pemerintah untuk membuat iklan layanan masyarakat mengenai Peraturan Wali Kota Denpasar Nomor 36 Tahun 2018 terkait pengurangan penggunaan kantong plastik sekali pakai agar masyarakat dapat menambah pengetahuan masyarakat. Contoh iklan layanan masyarakatnya dapat seperti contoh ibu yang berbelanja pada pagi hari membawa reusable bag sendiri atau membawa wadah makan besar ketika membeli bahan daging-dagingan.

Diharapkan dari pihat terkait seperti PD Pasar Kota Denpasar atau pemerintah 
untuk mengadakan sosialisasi dengan pembagian gratis kantong bioplastik yang terbuat dari tepung singkong. Namun, diharapkan setelah pengenalan akan bioplastik, penjual akan mengubah sikap dan perilaku dengan tidak menyediakan kantong belanja plastik sekali pakai.Serta kepada masyarakat terutama penjual di Pasar Badung Denpasar untuk melakukan kemandirian dalam mencari informasi mengenai pelarangan penggunaan kantong belanja plastik tanpa menunggu dari pihak PD Pasar Kota Denpasar ataupun pemerintahan terkait dan berpartisipasi aktif untuk mengoptimalkan Peraturan Wali Kota Denpasar Nomor 36 Tahun 2018 terkait pengurangan penggunaan kantong plastik sekali pakai.

\section{DAFTAR PUSTAKA}

Chandra, B. (2006). Pengantar Kesehatan Lingkungan. Jakarta: EGC.

CNN. (2016, 1 30). Indonesia Penyumbang Sampah Plastik Terbesar Kedua di Dunia. From http://www.cnnindonesia.com/gaya -hidup/20160222182308-277112685/indonesia-penyumbangsampah-plastik-terbesar-ke-duadunia/

Denpasar, S. D. (2018). Peraturan Walikota

Denpasar Nomor 36 Tahun 2018

Tentang Pengurangan Penggunaan

Kantong Plastik. Denpasar: Walikota Denpasar.

Ekawati, S. (2016). Mengkritisi Kebijakan Penanganan Kantong Plastik di Indonesia. Pusat Penelitian dan Pengembangan Sosial, Ekonomi, Kebijakan dan Perubahan Iklim, 1-4.

Guslaida, M. (2014). Hubungan Karakteristik Pengetahuan Dan Sikap Pada Pembeli Dan Pedagang Dengan Penggunaan Kantong Plastik Di Pasar Tradisional Firdaus Kecamatan Medan Tembung
Tahun 2014. . Universitas Sumatera Utara, 1-8.

Ismail, O. A. (2016). Persepsi Ibu Rumah Tangga Terhadap Kebijakan Kantong Plastik Berbayar. Bandung: Universitas Komputer Indonesia.

Kominfo, D. (2019, Juli 14). Pemerintah Kota Denpasar. From https://www.denpasarkota.go.id/be rita/baca/15090

Mintarsih, T. (2019, 1 30). Kebijakan Kantong Belanja Plastik Tidak Gratis. From http://www.menlhk.go.id/tinymcp uk/gambar/file/Kebijakan\%20Kanto ng\%20Belanja\%20Plastik\%20Tidak $\% 20$ Gratis.pdf

Sumbung, H. (2012). Hubungan Antara Pengetahuan Dan Sikap Dengan Tindakan Penjual Gorengan Di Kota Manado Dalam Mengurangi Penggunaan Kantong Plastik. Fakultas Kesehatan Masyarakat Universitas Sam Ratulangi, 1-7. 